\title{
TUNTEISTA TUKKOISESTI
}

Ethel BRUNDIN (2002). Emotions in motion, The strategic leader in a radical change process, Jönköping International Business School, Jönköping University, JIBS Dissertation Series No.012

Kahden suuren ruotsalaisen, teknologia-alan ja puuteollisuuden, firman johtajan käyttäyty- misen tutkiminen suurissa muutostilanteissa kahdeksantoista kuukauden ajan on tuottanut 360 -sivuisen väitöskirjan. Tarkoituksena tutkijalla on ollut selvittää tunteiden merkitystä ja esiintymistä rationaalisessa toimintaympäristössä. Tavoite on loistava ja lopputulos melkoisen laiha: tunteilla on merkitystä strategisessa johtamisessa ja johtajuudessa. Millaista merkitystä: lähtekäämme katsomaan.

Tutkija on toiminut vuosia konsulttina yritysmaailmassa ja niin omassa työssään kuin konsultoimissaan organisaatiossa havainnut, ettei tunteita paljoakaan käsitellä. Niille ei anneta sijaa tulla esiin keskusteluissa. Tämän meistä moni on käytännössä myöskin havainnut. Kir- 
joittaja käy läpi laajaa tunteisiin ja strategiseen johtamiseen liittyvää kirjallisuutta, valitettavasti kirjallisuuden läpijuoksutus ei kovin uusia uria aukaise. Turbulenssissa tilanteessa johtajien oletetaan käyttäytyvän rationaalisesti. Minzbegin ei-tarkoitukselliset ja tarkoitukselliset strategiat kirjoittajan mukaan kuvaavat sitä, että raju muutosprosessi vaatii prosessuaalista työtä - tyyliin "palapelin rakentaminen".

\section{TÄRKEÄT PÄÄTÖKSET JOHTAJAN \\ MENTAALINEN PROSESSI}

Suurena uutisena saamme lukea, että raju muutos on sosiaalisesti tuetettu prosessi. Strateginen johtajuus (leadership) muotoutuu arjen kommunikaatiossa. Arjen kommunikaatioon taas vaikuttavat kulttuurinen tausta ja historialliset tapahtumat. Strategiset - lue tärkeät päätökset (kirjoittajan oletuksen mukaan) muotoutuvat epävirallisissa keskusteluissa ja tapaamisissa, myös toki virallisissa kokouksissa. Tärkeät päätökset ovat johtajan mentaalinen prosessi, jossa tunteet ovat mukana. "Päätöksiä tehdään paikassa kuin paikassa ja mihin kellon aikaan hyvänsä".

Johtaminen - niin strateginen kuin vähemmän tärkeäkin, on vuorovaikutusprosessi eri toimijoiden välillä. Tämä on ko. väitöskirjan lähtötilanne pitkän strategista johtamista käsittelevän kirjallisuuskatsauksen jälkeen, kirjallisuuskatsauksen, joka sisältää paljon mielenkiintoisia ruotsalaisia tutkimuksia.

Tunteita kirjoittaja lähestyy niinikään laajan kirjallisuuskatsauksen avulla: joidenkin filo- sofisten teorioiden, biologien, kognitiivisten teorioiden, psykologisten, sosiaalikonstruktivististen. Hochschildin hän luokittelee poliittisten ja sukupuoliteorioiden alle: pintakäyttäytyminen, siis teeskennellään jokin ilme, jotta muut luulisivat tunnetta olevan mukana, ja syvä käyttäytyminen, siis ei yksinomaan ilmeissä näkyvää, vaan aitoa, olemme muuttaneet myös syyn tuntea jotain tunnetta. Organisaatiokulttuurien kautta kirjoittaja päätyy integroituun tunnekäsitykseen: tunteet ovat niin kognitiivisia, kulttuurisia ja somaattisia. Oman näkemyksensä kirjoittaja kuvaa sosiaalisesti konstruoiduksi. Tunteetkin ovat sosiaalisesti tuotettuja.

\section{TUNTEIKSI TÄSSÄ MYÖS TIIMIHENKI JA YSTÄVYYS}

Kirjoittaja käsittelee mm. seuraavia ilmiöitä tunteina: onnellisuus, viha, pelko, pettymys, toivo, ilo, hämmästys, inho, viha, kateus, mustasukkaisuus, myötätunto, sääli, nolous jne., mutta myös sellaiset kuin tiimihenki ja ystävyys ovat hänen tunneluettelonsa listalla. Hän jopa toteaa, että organisaatiokulttuuriksi kutsumassamme ilmiössä on tunteita mukana! Kommunikatiivisella lähestymistavalla (ie. vuorovaikutusta tutkimalla) voidaan tutkia tunteita, niiden ilmenemismuotoja ja muuttumista. Hermeneuttisella lähestymisotteella kirjoittaja selvittää tunteiden ilmenemistä voimakkaissa muutostilanteissa.

Tutkimus seuraa puolentoista vuoden ja intensiivisemmin pari neljän kuukauden ajanjakson verran vuosina 1998 - 1999 kahta johtajaa, (puuteollisuuden ja korkean teknologian yritys) haastatellen myös yhtiöiden työntekijöitä ja tutustuen yhtiöi- den historiaan ja markkinoihin. Narratiivisen aineiston ja tapauskuvausten jälkeen kirjoittaja kategorisoi strategisia muutoksia vaativissa markkinatilanteissa päätöksiä tehneiden johtajien tunteita. Shaverin ja kumppaneiden vuonna 1987 laatiman tunteiden luokituksen avulla - tunteita yhdistellen ja joitakin pois jättäen - tutkija tuottaa johtajien ja johtoryhmien tunnepaletin.

\section{MUUTOSTILANTEET NOSTAVAT TUNTEITA}

Tuotantotapoihin, taloudellisiin asioihin, organisointiin jne. liittyviin muutoksiin tunnetilat vaihtelevat ovat hylkäämisestä frustraatioon, tyytyväisyydestä hämmennykseen. Eli tunteita ilmeni eri muutostilanteissa. Miksi niitä ilmeni, mitä rakenteellisia tekijöitä oli tuottamassa tai estämässä joidenkin tunteiden syntymistä, ei selvitetä, eikä se ole tutkijan tarkoituskaan. Tukijalle on riittänyt tulos, että tunteita on olemassa! Johtajat välittävät ja viestivät tunteita muutostilanteissa.

Kirjassa on paljon kirjallisuuden referointia, mutta esimerkiksi tunneälyyn viittaavista tutkimuksista ei ole mainintaakaan. Paksun kirjan jälkeen jää sama tunkkainen maku suuhun kuin kiinalaista ruokaa tarjoavasta ravintolasta, jossa ruoka on valmiista lukuisista purkeista ja lisätty valmiita maustekastikkeita - jokin omatekoinen kastike olisi tuonut raikkautta.

\section{Tuija Mäkinen}

